\title{
"The social worker's practice of his professional roles to alleviate the problems caused by bullying among dwarves"
}

\section{Prepared by}

\begin{tabular}{|c|c|}
\hline Om El-Saad Fathy Ibrahim Issa & Saima Ibrahim Younis Ali \\
\hline $\begin{array}{c}\text { Teacher At the Department of Working with } \\
\text { Groups }\end{array}$ & $\begin{array}{c}\text { Teacher at the Department of Social Work } \\
\text { Fileds }\end{array}$ \\
\hline Faculty of Social work & Faculty of Social work \\
\hline Helwan University & Helwan University \\
\hline
\end{tabular}




\title{
"The social worker's practice of his professional roles to alleviate the problems caused by bullying among dwarves"
}

\begin{abstract}
:
The current study aims to determine the nature of the social worker's practice of his professional roles to alleviate the problems caused by bullying among dwarves, through the application of a questionnaire form to the social workers working in the Egyptian dwarfs association in Alexandria, numbering (10) specialists, a questionnaire applied to a random sample of dwarves and their number (50) dwarfs, and the results of the study showed that the level of the social worker's practice of his roles to alleviate the problems caused by bullying among dwarves is high as identified by specialists and dwarves, which makes us accept the first hypothesis, and it was found that the level of difficulties that hinder the social worker's exercise of his roles to alleviate problems The result of bullying among dwarves is low, which makes us reject the second hypothesis, in addition to the fact that the level of proposals that help the social worker to exercise his roles to alleviate the problems caused by bullying among dwarves, which makes us accept the third hypothesis, and the results showed that there are significant differences between the point of view of social workers And the view of the dwarves about the roles of the social worker to mitigate the problems caused by bullying For dwarves, the value of the T-test was $\left(2.851^{* *}\right)$, which is significant at (0.01), in favor of the viewpoint of social workers, which makes us reject the fourth hypothesis of the study.
\end{abstract}

Key words:

Dwarves - Bullying - Problems caused by bullying. 


\section{"ممارسة الأخصائي الاجتماعي لأدواره المهنية للتخفيف من

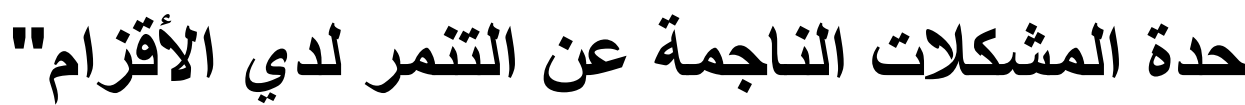

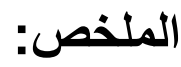

تهدف الدر اسة الحالية إلى تحديد طبيعة ممارسة الأخصائي الاجتماعي لأدواره المهنية للتخفيف

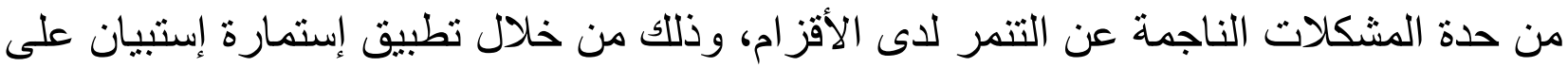

الأخصائيين الاجتماعيين العاملين بجمعية الأقز ام المصرية بالأسكندرية و عددهم (10) أخصائيين، إستمارة إستبيار مطبقة على عينة عشو ائية من الأقز ام و عددهم (50) قزم، وأوضحت نتائج الدر اسة أن مستوى ممارسة الأخصائى الاجتماعى لأدواره للتخفيف من حدة المشكلات

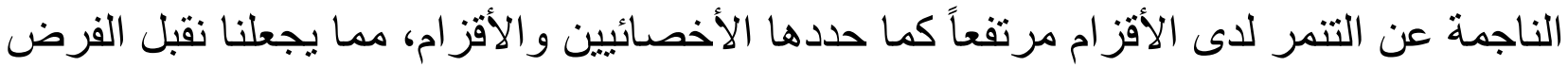
الأول، كما تبين أن مستوى الصعوبات التى تعوق ممارسة الأخصائى الاجتماعى لأدواره

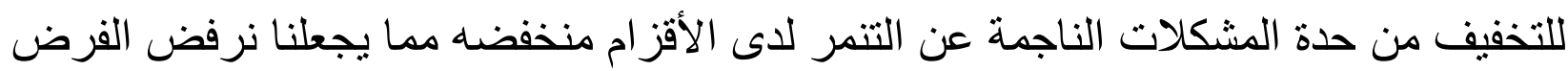
الثانى، بالإضـافة إلى أن مستوي المقترحات التى تساعد الأخصائى الاجتماعى على ممارسة

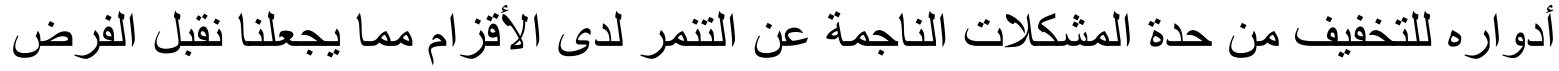
الثالث، كما أوضحت النتائج وجود فروق معنوية بين وجهة نظر الأخصائيين الاجتماعيين

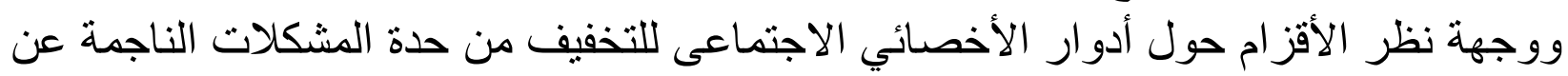

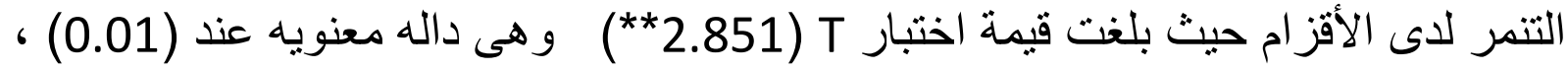
وذللك لصالح وجهة نظر الأخصائيين الاجتماعبين، مما بجعلنا نرفض الفرض الر ابع للار اسة. 


\section{Introduction:}

The human element is the focus of progress and development for any society and the real driving force for the development process, hence the interest in the need to develop human resources on the basis that the human being is the end of development and at the same time its means. (Talaat AlSrouji, 2009, p.9) Despite the interest in the human element, whether in developed or developing countries, it is exposed to many problems, whether health, social, and others. Contemporary changes have resulted in the growth of marginalized social groups that necessarily need conscious social, rehabilitation or medical efforts to enable them to lead an independent life. These groups They have very special needs and problems, even though they tend to be healthy and normal, and at the same time they need special services and organized care. (Mustafa Muhammad Qassem, Youssef Muhammad Abd al-Hamid, 2006, p. 5). Those challenges increase, especially if the youth of today and the men of the future are the ones who suffer from disabilities, especially if the disability is physical such as stunting, which loses the person's ability to coexist with others, as well as losing him adapt to the environment in which he lives, especially if we live in a society that deals with This class as being from another faction of human beings. The term dwarfism is not considered a derogatory term only, it is a term that expresses their physical and medical condition. They are equal with humans in the same rights and duties, and they have their distinctive characteristics and distinctive shape. Rather, they can do things that no one else can do. The dwarf is not another faction of humans, but He is a human being in all senses, and the sanctity of his humanity should not be violated, and we must sanctify and glorify the Creator's wisdom in creating him in this image, whatever it may be. (Reem Ibrahim Khallaf, 2015, p. 1077) Medical studies and research also confirm that (dwarfism) occurs as a result of slowing growth in children, and stunting begins in elderly individuals with a level of length of $147 \mathrm{~cm}$ and below. As for the most important causes of dwarfism, it comes as a result of the lack of osteochondrosis, which causes (70\%) of dwarfism cases, and the child is often of medium height parents. (Information, Support and Decision-Making Center of the Egyptian Government: 2012, 317) The number of dwarfs in the world, according to the 2018 census, is estimated at about $(250,000)$ dwarfs (two hundred thousand dwarfs), and their number in Egypt only $(75,000)$ is seventy thousand dwarfs, which means that the percentage of dwarfs in Egypt is (45\%) of the total dwarfs in the world, which is a percentage It places it in an advanced position in the list of countries where the number of dwarves is increasing. (Central Agency for Public Mobilization and Statistics, 2018).

Accordingly, pygmies were recently recognized as one of the disabled groups, as they were constitutionally recognized in the 2014 amendment to the constitution, which included them in employment quotas. The amendment also gave special attention to this category with regard to social and economic rights, as Article (81) stipulates:- The state is obligated to guarantee the rights of persons with disabilities and dwarves, in health, economically, socially, culturally, and recreationally, in sports and in education, and to provide them with job opportunities, allocating a percentage of them to them, creating public facilities and the environment around them, exercising all political rights, and integrating them with other people. Citizens, in implementation of the principles of equality, justice and equal opportunities." (Arab Republic of Egypt, Constitution Amendments, 2014, p. 24). 
This category suffers from many problems in their lives, due to the poor physical composition, social problems, difficulty of movement and problems providing their own clothes, as well as problems in places of residence or work, and there are many psychological problems within the family, different social situations, and in the workplace, which It leads to incompatibility in their society. (Jessicac.Robert, 2000,P.P119 -130 ) In addition, the category of dwarfs needs a deep and permanent diagnosis that includes the behavior of the disabled, his needs and problems, through a serious professional relationship through which it is easy to influence him to be more flexible. Because a disabled person is usually more sensitive in dealing with others because of his constant feeling of inferiority or helplessness, which makes others find it difficult to approach him, deal with him, or participate in work together. (Tariq Abdel-Raouf, Rabie Muhammad: 2008, 189) One of the most important factors and reasons that lead to the existence of problems for this group is the phenomenon of bullying, despite the fact that all heavenly religions forbid ridicule of others and this is evident in the Almighty's saying: ((O you who believe! Nor women from women, perhaps he is better than them, and do not defame yourselves, and do not call each other by name. Evil is the name, immorality after faith. In spite of this, we find that there is an increase in the prevalence of bullying within developing societies, including those presented to this group, and they make them a subject for ridicule, sarcasm and bullying, which makes this group (dwarves) always feel inferior and socially marginalized. Bullying is one of the important problems facing societies, which entails many problems of social compatibility for the individual, because it limits his interactions and participation with others, limits his integration into society, negatively affects his social compatibility and prevents him from providing him with the necessary life skills, and does not fully benefit from experiences The educational and professional benefits that the average individual can benefit from, thus limiting his participation in the development of his society. (W.h.o:2000).

The category of dwarves is one of the groups that fall among the victims of bullying and who suffer from many psychological, social and economic problems, as a result of bullying behavior, which leads them to withdraw as a result of the feeling that society rejects them, low self-esteem and their inability to communicate and establish social relationships with others, and this is what Numerous studies and research confirmed it, and what increases the problem of bullying is that the victims of bullying behavior are silent despite their torment and do not tell anyone about their being a victim of bullying, and this may be due to their sense of inferiority and shame, believing that speaking will not change anything. This is what was confirmed by the study (Sampson, E, 2004), and this study agrees with the study (Raniah Bin Ziwal, Hadda Yossef,2019), which found that victims of bullying are characterized by a low assertiveness skill compared to ordinary people. The problem of friendship is also a manifestation of the disorder of relations between dwarves and their peers through his lack of sense of equality with his colleagues and friends and the inadequacy of these people. Which leads to negative responses to make the disabled person shrink and withdraw from this friendship. (Mohammed Sayed Fahmy: 2000, 47) This was confirmed by a study (Cohn, A, and Canter, A, 2003), which dealt with the social relationships of bullies and their victims, which showed that victims of bullying suffer from loneliness and social exclusion and lack the social skills that help them establish social relationships, as well as withdrawal and the scarcity of friends. The study of the US National Institute of Health also showed that bullying has long- and short-term psychological effects on those who are exposed to it (victims). Victims feel lonely, and will suffer from social and emotional troubles, difficulty forming friendships and bad relationships with 
colleagues, and often suffer humiliation and humiliation. Insecurity and loss of safety, and that it may develop into fear of going to school and these many effects of bullying accompany these victims in adulthood, and one of the most dangers to the victims is that they reach the stage of depression, schizophrenia, anxiety, and may lead to suicide. (American Medical Association, 2002) This was confirmed by the study (Bonanno etal, 2010, 420-440), which found a relationship between bullying and suicidal ideation, especially if the victims of bullying did not receive any support or support from the family, and that suicidal ideation was lower in the case of family support. or support. This was also confirmed by a study (Ragby Wesley 1990), which aimed to study the relationship between bullies and victims of school bullying, their desire to commit suicide, the problems they face, and the extent of social support for them. To receive social support from others. Also, constant exposure to bullying may lead to symptoms of anxiety, which negatively affects the social relationships of bullying victims. We find that bullying victims always tend to be isolated because of social exclusion and low social status. (The Nun Al-Adly, and Ashwaq Jabr: 2016) This was confirmed by the results of the study (Preston and Andrew 2005), which found a relationship between tension and internal and external maladaptation of dwarves with their ordinary peers and those around them, and the disruption of their social relationships, which are mostly characterized by anger and a feeling of persecution and inferiority and others and looking at them and mocking their short length. (Perston, Andrew, 2005), and a study (Andreow, 2004), which found that victims of bullying have low self-esteem, as well as a failure to form relationships (friends) and interact with peers. A study (Nihal Sami, 2017) indicated that dwarfs suffer from social problems to a high degree on all forms, and the highest rates of social problems for dwarves are related to the social system, which is $90 \%$, which indicates the suffering faced by this group of society in which they live. Dwarves also suffer from work-related problems, as dwarfism may lead to leaving work or changing it to suit their new situation, as well as problems related to their relationship with colleagues and superiors. (Maher Abu Al-Maati Ali: 2000, 134).

In addition to psychological problems such as (excessive feeling of inferiority, worthlessness and importance, excessive feeling of helplessness, and lack of psychological security for them) and this was indicated by the study of (Syed Ahmed Ahmed Al-Bahaqat), where it found that there is an increase in the level of anxiety, rejection of the companion, negativity and inferiority, and a decrease in the concept of Self and withdrawal tendencies among victims of bullying. This is what I aimed to study (Reem Ibrahim Khalaf, 2015), which aimed to identify the relationship between psychological adjustment and social phobia among university dwarves, and its results found that there is a correlation between the dimensions of the psychological adjustment scale and the social phobia scale among university dwarves, and the existence of a relationship between the adjustment scale. And the measure of the self-concept of dwarves at the university, and the study recommended the importance of paying attention to the development and development of psychological compatibility for dwarves at the university. Conducting more studies and research related to psychological compatibility among dwarves. The dwarfs also suffer from many social problems, and this was confirmed by a study (Filjlamson et al. 2012), that dwarves suffer from withdrawal from social situations and low self-concept as a result of being subjected to continuous bullying by their peers and through the community surrounding them. (Vilhjalmssonrunner et al, 2012, 102).

The results of the study (Ahmed Mohamed Heby,2017) added that dwarfs tend to isolate themselves and do not share socially with others, whether it is personal, public, or even voluntary, which 
confirms the high rates of isolation they have before and after professional intervention. The profession of social work is one of the professions that seeks to provide social care in general, and the field of caring for the disabled is one of the fertile areas for practicing social work, on the grounds that this profession works with individuals and social systems that provide them with services and resources, and aims to increase the effectiveness of these systems on To carry out its functions, on the basis of the interrelationship between individuals and society, and therefore it is a profession to practice. (Maryam Ibrahim Hanna: 2010, 74) Within the framework of what was presented from previous studies and theoretical writings, the problem of the study crystallizes in a question that leads to: What is the nature of the social worker's practice of his professional roles to alleviate the problems caused by bullying among dwarves?

\section{the importance of studying:-}

1- The percentage of dwarfs in Egypt is estimated (45\%) of the total dwarfs in the world, which is a high percentage that emphasizes the need to pay attention to the problems of this group.

2- The dwarfs category is one of the disabled categories that need attention and care from the institutions of society, as this category suffers from many problems in their lives.

3- This group is exposed to ridicule and bullying due to its meager physical composition, which leads to their suffering from many problems (psychological, social, educational, work), which is reflected in their compatibility with their society.

4- Enriching the knowledge aspect that helps social workers and specialists working with this group in how to deal with the problems of dwarves, which helps them to adapt to society.

\section{Objectives of the study :-}

The main objective:- Determining the nature of the social worker's practice of his roles to alleviate the problems caused by dwarves bullying .

\section{A set of sub-goals emerge from it:}

1- Determining the nature of the social worker's practice of his roles to alleviate the social problems caused by bullying among dwarves.

2- Determining the nature of the social worker's practice of his roles to alleviate the psychological problems caused by bullying among dwarves.

3- Determining the nature of the social worker's practice of his roles to alleviate the educational problems caused by bullying among dwarves.

4- Determining the nature of the social worker's practice of his roles to alleviate the economic problems caused by bullying among dwarves.

\section{Study hypotheses:}

1- It is expected that the level of the social worker's exercise of his roles to alleviate the problems caused by bullying among dwarves will be high.

2- It is expected that the level of difficulties that hinder the social worker's exercise of his roles to alleviate the problems caused by bullying among dwarves will be low.

3- It is expected that the level of suggestions that help the social worker to exercise his roles to alleviate the problems caused by bullying among dwarves will be high. 
4- There are no fundamental differences between the point of view of social workers and the point of view of dwarves about the social worker's practice of his roles and the mitigation of the problems caused by bullying among dwarves.

\section{Study Concepts:}

\section{1- The concept of dwarfs}

A "dwarf" is a diminutive, short-lived body." (The Brief Dictionary: 1999, 501) It is also known as: "A person who is very short, who is very short in height compared to people of the same age or of normal sizes." (Oxford, 2009, p246) Biologically, dwarfs are: "individuals whose length of the adult male does not exceed $130 \mathrm{~cm}$, and the adult woman is $121 \mathrm{~cm}$." Dwarfism is a pathological condition resulting from the deficiency of hormones secreted by one of the thyroid and pituitary glands, and corresponds to pathological phenomena such as dullness, rapid fatigue, premature aging and body inconsistency. Childhood may continue beyond puberty. (Mohamed Mostafa Zeidan, Mohamed El-Sherbiny: 2004, 58) There is a confusion in the concepts of the members of society between the concept of dwarves and short stature, there are those who call dwarves of short stature, and there are those who call dwarves of short stature, and this is incorrect from a scientific point of view. Dwarfism is also defined as: "Shortening due to a medical condition". It is sometimes defined as: "The height of adults is less than (4) feet (10) inches $(147 \mathrm{~cm})$, and the causes of dwarfism are due to about 200 causes, most of which are genetic or hereditary, and bone growth disorder is responsible for $70 \%$ of dwarfing cases. The parts of the body are disproportionate, and the cause is usually hormonal (such as (growth hormone deficiency), or genetic mutations, as well as metabolic problems and malnutrition, and the affected group is exposed to many health problems."

(Mohammed Mostafa Zeidan, Mohamed El-Sherbiny: 2004, 56) Procedural definition of dwarves: They are a category ranging in length from $(130 \mathrm{~cm}$ to $140 \mathrm{~cm})$. She suffers from social, psychological, educational and economic problems. They are subjected to bullying behavior by those around them and society. They benefit from the services of the Egyptian Dwarfs Association in Alexandria.

\section{2- The concept of bullying}

Bullying is defined linguistically as: "It is said to a man of bad manners: He may bully and bully, and his face, i.e. others, will bully and frown" (Abi al-Fadl Jamal al-Din: 1997, 115). Bullying is defined in its general sense as: "a state of repeated negative behavior, intentionally harming or harassing, by a strong person against a less powerful person." (Ahmed Hassan Muhammad, Muhammad Muhammad Darwish: 2017, 205) It is also defined as: "a socially acceptable act of a person who is larger, more controlled and more powerful than someone who is weaker than him, in which the stronger person has a compelling desire to repeatedly inflict harm and pain upon the weaker." (Omaima Abdel Aziz: 2012, 17) Bullying can be defined procedurally as:

- A form of verbal and nonverbal harassment.

- Caused by an unbalanced force between the bully and the victim (dwarves).

- intentionally and intentionally committed against the bully.

- Falls through a single individual or group of individuals. 
- It results in a feeling of psychological and physical harm to the bully (dwarves).

\section{3- Concept of problems:}

Linguistically, the problem is defined as the confusion of the matter (Lisan Al Arab, 654). It is known as social situations that confront society as individuals, groups, bodies and as a society, and the available resources of society, especially its existing social systems and facilitating resources, are unable to confront them (Samah Salem et al., 120). What is meant by the problems in the current study: that they are the social, psychological, educational and economic problems facing the dwarves as a result of bullying them.

\section{Theoretical Guidelines for the Study:-}

role theory. The role theory is one of the leading theories in social work science, through which the nature of the roles played by the social worker in his field of work is determined. The role is defined as a set of skills and responsibilities that determine the behavior of the individual occupant of the specified position within the framework of the cultural pattern. (Robert L. Barker, 1999, P4.) It is also known that it represents the dynamic aspect of status, which distinguishes it from other statuses. The status is the social status occupied by the member, while the role is the behavior that the member performs to achieve the society's expectations of him as an occupation of this social status. (Mohamed Abu Al-Nasr, Medhat, 2004, p. 233).

One of the main roles played by the social worker to reduce the problems caused by bullying among dwarves The role that is related to alleviating the social problems caused by bullying among dwarves. The role that is related to alleviating the psychological problems caused by bullying among dwarves.

The role that has to do with alleviating the educational problems caused by bullying among dwarves. The role that has to do with alleviating the economic problems caused by dwarves bullying.

\section{The methodological procedures of the study:-}

1- Type of study: This study belongs to the type of descriptive studies, which are concerned with describing social phenomena such as the problems caused by bullying among dwarves.

2- The method used: - Social survey method comprehensive inventory of dwarves. - Social survey approach in a comprehensive inventory method for social workers working with dwarves in the Egyptian dwarfs association in Alexandria.

\section{3- Study tools:}

- A questionnaire form applied to social workers to identify the reality of their practice of their professional roles in dealing with problems resulting from bullying among dwarves.

- A questionnaire applied to dwarves to identify problems resulting from bullying.

\section{The study tools were identified as follows:-}

A- Questionnaire form applied to social workers working in the Egyptian Pygmies Association in Alexandria

B- An inquiry form applied to dwarves who benefit from the services of the association.

Study tool design: A questionnaire applied to social workers, a questionnaire applied to dwarves, and they were designed according to the following steps: The researchers benefited 
from previous studies on the phenomenon of bullying, and the questions of the questionnaires were answered through the following items: Agree $=3$ marks, somewhat agree $=2$ marks, disagree $=1$ mark

Table (1): Arithmetic averages level

\begin{tabular}{|l|l|}
\hline If the mean value of the expression or dimension ranges between 1-1.67, & low level \\
\hline $\begin{array}{l}\text { If the mean value of the expression or dimension ranges between more than 1.67 - } \\
2.34\end{array}$ & $\begin{array}{l}\text { Medium } \\
\text { level }\end{array}$ \\
\hline If the mean value of the expression or dimension ranges between more than 2.34:3 & High level \\
\hline
\end{tabular}

\section{fields of study:-}

A)- Human field: A sample of (50) dwarves, a comprehensive inventory of all (10) social workers.

B)- Spatial domain:- The Egyptian Dwarfs Association in Alexandria. c) Time domain: the period of data collection and analysis.

\section{Results of the study:}

Findings related to social workers

Table No. (2) shows the description of the study community (social workers)

\begin{tabular}{|c|c|c|c||}
\hline \hline $\mathbf{S}$ & Gender & $\mathbf{N}$ & $\%$ \\
\hline 1 & Male & 6 & $60 \%$ \\
\hline \hline 2 & Female & 4 & $40 \%$ \\
\hline $\mathbf{S}$ & Age & $\mathbf{N}$ & $\%$ \\
\hline \hline 1 & From 25 to 35 years old & 4 & $40 \%$ \\
\hline 2 & From 35 to 45 years old & 4 & $40 \%$ \\
\hline 3 & From 45 to 55 years old & 2 & $20 \%$ \\
\hline 4 & 55 years and over & - & - \\
\hline \hline $\mathbf{S}$ & Educational qualification & $\mathbf{N}$ & $\%$ \\
\hline \hline 1 & Intermediate Diploma in Social Work. & 3 & $30 \%$ \\
\hline 2 & Bachelor Social Work. & - & - \\
\hline
\end{tabular}




\begin{tabular}{||c|c|c|c||}
\hline 3 & Bachelor of Arts (Social Department) & 3 & $30 \%$ \\
\hline 4 & Diploma in Social Work. & - & - \\
\hline 5 & Master's in Social Work. & - & - \\
\hline 6 & PhD in social work. & - & - \\
\hline 7 & Other remembe. & 4 & $40 \%$ \\
\hline \hline S & Years of experience in the field of work & $\mathbf{N}$ & $\%$ \\
\hline \hline 1 & Less than 4 years & 6 & $60 \%$ \\
\hline 2 & From 4 to less than 8 years & 3 & $30 \%$ \\
\hline 3 & From 8 to less than 12 years & 1 & $10 \%$ \\
\hline 4 & From 12 years and over & - & - \\
\hline
\end{tabular}

The table above shows that:

- Describing the social workers in terms of gender, it was found that the largest percentage of males was $(60 \%)$.

- The description of social workers in terms of age came in the first place (from 25 - 35 years), (from 35 - 45 years) with a percentage of $(40 \%)$.

- The description of social workers in terms of educational qualification came in the first place (Bachelor of Intermediate Diploma in Social Work), (Bachelor of Arts (Social Department)) with a percentage of (30\%), and this shows the importance of specializing the profession of social work and its effectiveness in dealing with the problems of dwarves.

-The description of social workers in terms of years of experience in the field of work came in the first place (less than 4 years) at a rate of (60\%), followed by (from 4 to less than 8 years) at a rate of (30\%), and this confirms the recent establishment of the Egyptian Pygmies

Association Where it was established in 2012.

- Results related to the study population (dwarfs)

Table No. (3) shows the description of the study community (dwarves)

\begin{tabular}{|c|c|c|c||}
\hline $\mathbf{S}$ & Gender & $\mathbf{N}$ & \multicolumn{1}{|c|}{$\mathbf{\text { N=50 }}$} \\
\hline \hline 1 & Male & 17 & 34 \\
\hline 2 & Female & 33 & 66 \\
\hline $\mathbf{S}$ & Age & $\mathbf{N}$ & $\%$ \\
\hline \hline 1 & From 18 - 28 years old & 14 & 28.0 \\
\hline 2 & From 28 - 38 years old & 12 & 24.0 \\
\hline 3 & From 38 - 48 years old & 17 & 34.0 \\
\hline
\end{tabular}




\begin{tabular}{|c|c|l|l||}
\hline 4 & From 38 - 48 years old & 7 & 14.0 \\
\hline 5 & 48 years and over & 14 & 28.0 \\
\hline \hline $\mathbf{S}$ & Educational level & $\mathbf{N}$ & $\%$ \\
\hline 1 & Illiterate & 13 & 26.0 \\
\hline 2 & Read and write & 18 & 36.0 \\
\hline 3 & Intermediate Diploma & 16 & 32.0 \\
\hline 4 & bachelors degree & 3 & 6.0 \\
\hline \hline $\mathbf{S}$ & Educational Status & $\mathbf{N}$ & $\%$ \\
\hline 1 & Unmarried & 30 & 60.0 \\
\hline 2 & Married & 17 & 34.0 \\
\hline 3 & Widower & 1 & 2.0 \\
\hline $\mathbf{S}$ & Absolute & $\mathbf{N}$ & $\mathbf{\%}$ \\
\hline $\mathbf{2}$ & functional status & 68.0 \\
\hline
\end{tabular}

\section{The table above shows that:}

- Description of the dwarfs in the study population in terms of gender. It was found that the largest percentage of pygmies are females with a rate of $(66 \%)$, which is in line with the demographic variables in the Egyptian society, as the percentage of women is higher than the percentage of men in the population in general and this is consistent with the theoretical framework of the study.

- The pygmies described the study population in terms of age, as it came in the first place (from 38 - 48 years) with a percentage of (34\%), followed by (from 18 - 28 years) at a rate of (28\%), and this confirms the diversity of age groups that frequent the community to benefit From the services you provide to the dwarves category.

- The dwarves described the study community in terms of educational status came first (read and write) at a rate of (36\%), followed by (intermediate diploma) at a rate of (32\%), and this confirms the deterioration of the educational level of the dwarfs category as they drop out of education as a result of bullying that occurs They are subjected to by the community surrounding them, and this is consistent with the results of the study (Tran, Uyen, n, etal, 2010), which confirmed the low educational level of the dwarves, and the study of Abd- Allah, N, Drummond, 2009) confirmed that dwarves suffer from Learning difficulties due to physical characteristics and low IQ.

- The description of the dwarves of the study community in terms of social status came in the first place (single) by (60\%), followed by (married) by (34\%), which indicates that the dwarfs category faces many social problems such as the difficulty of having a life partner who accepts physical conditions And their health, whether a young man or a girl, and therefore we find that most dwarves 
have weak marriage opportunities available to them, and this is what was indicated by (Mohammed Nabil Saad, 2000, p. 78), where he emphasized the high rates of spinsterhood among dwarves due to social and economic conditions and added that the reason for their suffering is not Because of their short stature but because they are constantly bullied by the society around them.

- The description of the dwarves of the study population in terms of employment status came in the first place (does not work) by (68\%) followed by (works) by (32\%), and this confirms that the dwarfs category suffers from unemployment significantly and that whoever works is doing free work and not in Jobs within the state's administrative apparatus.

The results associated with the hypothesis test.

The first hypothesis: It is expected that the level of the social worker's exercise of his roles to alleviate the problems caused by bullying among dwarves will be high.

Table (4) shows the level of the social worker's exercise of his roles to alleviate the problems caused by bullying among dwarves.

\begin{tabular}{|c|c|c|c|c|c|c|c|c|c|}
\hline \multirow[t]{2}{*}{$\mathbf{S}$} & \multirow[t]{2}{*}{ The dimension } & \multicolumn{4}{|c|}{ social workers $(\mathrm{N}=10)$} & \multicolumn{4}{|l|}{ dwarves } \\
\hline & & $\begin{array}{l}\text { average } \\
\text { weight }\end{array}$ & $\begin{array}{l}\text { standard } \\
\text { deviation }\end{array}$ & $\begin{array}{l}\text { The } \\
\text { level } \\
\text { order }\end{array}$ & ranking & $\begin{array}{l}\text { average } \\
\text { weight }\end{array}$ & $\begin{array}{l}\text { standard } \\
\text { deviation }\end{array}$ & $\begin{array}{l}\text { The } \\
\text { level } \\
\text { order }\end{array}$ & ranking \\
\hline 1 & $\begin{array}{l}\text { The social worker's } \\
\text { practice of his roles to } \\
\text { alleviate the social } \\
\text { problems caused by } \\
\text { bullying among } \\
\text { dwarves }\end{array}$ & 2.58 & 0.217 & High & 4 & 2.68 & 0.224 & high & 1 \\
\hline 2 & $\begin{array}{l}\text { The social worker's } \\
\text { practice of his roles to } \\
\text { alleviate the } \\
\text { psychological problems } \\
\text { caused by bullying } \\
\text { among dwarves. }\end{array}$ & 2.70 & 0.302 & High & 3 & 2.42 & 0.265 & high & 4 \\
\hline 3 & $\begin{array}{l}\text { The social worker's } \\
\text { practice of his roles to } \\
\text { alleviate the } \\
\text { educational problems } \\
\text { caused by bullying } \\
\text { among dwarves. }\end{array}$ & 2.75 & 0.206 & High & 1 & 2.50 & 0.193 & high & 3 \\
\hline 4 & $\begin{array}{l}\text { The social worker's } \\
\text { exercise of his roles to } \\
\text { alleviate the economic } \\
\text { problems caused by } \\
\text { bullying among } \\
\text { dwarves. }\end{array}$ & 2.70 & 0.300 & High & 2 & 2.58 & 0.216 & high & 2 \\
\hline \multicolumn{2}{|c|}{$\begin{array}{l}\text { average dimension as a } \\
\text { whole }\end{array}$} & \multicolumn{4}{|c|}{2.68 high } & \multicolumn{4}{|c|}{2.54 high } \\
\hline & standard deviation & \multicolumn{4}{|c|}{0.222} & \multicolumn{4}{|c|}{0.113} \\
\hline
\end{tabular}

The table above shows that:

- The level of the social worker's practice of his roles to alleviate the problems caused by

bullying among dwarves, as determined by specialists, is high with an average weight of (2.68). 
- The level of the social worker's practice of his roles to alleviate the problems caused by bullying among dwarves, as determined by the dwarves, is high with an average weight of (2.54). Which makes us accept the first hypothesis of the study, which is that "the level of social workers' practice of their roles to alleviate the problems caused by bullying among dwarves is expected to be high", which confirms the effectiveness of social workers' practice of their roles to alleviate the problems caused by bullying among dwarves, such as social, psychological problems., educational and economic, and this agrees with the research literature and the results of the study (Mohamed Ezzat, Ali Abdullah, 2015), which confirmed the effectiveness of a proposed conception from the perspective of general practice in social work to alleviate social, psychological, educational and economic pressures for short people.

The second hypothesis: It is expected that the level of difficulties that hinder the social worker's exercise of his roles to alleviate the problems caused by bullying among dwarves will be low.

Table (5) shows the level of difficulties that hinder the social worker's exercise of his roles to alleviate the problems caused by bullying among dwarves.

\begin{tabular}{|c|l|l|l|l|l|l|l|}
\hline \multirow{2}{*}{$\mathbf{S}$} & \multicolumn{2}{|c|}{ The dimension } & \multicolumn{3}{c|}{ social workers $(\mathrm{N}=10)$} & dwarves & \\
\cline { 3 - 7 } & & $\begin{array}{c}\text { average } \\
\text { weight }\end{array}$ & $\begin{array}{c}\text { standard } \\
\text { deviation }\end{array}$ & $\begin{array}{c}\text { The level } \\
\text { order }\end{array}$ & $\begin{array}{c}\text { average } \\
\text { weight }\end{array}$ & $\begin{array}{c}\text { standard } \\
\text { deviation }\end{array}$ & $\begin{array}{c}\text { The } \\
\text { level } \\
\text { order }\end{array}$ \\
\hline $\mathbf{1}$ & $\begin{array}{l}\text { Difficulties that impede the } \\
\text { social worker's exercise of his } \\
\text { roles to alleviate the problems } \\
\text { caused by bullying among } \\
\text { dwarves. }\end{array}$ & $\mathbf{1 . 7 1}$ & $\mathbf{0 . 4 2 3}$ & medium & $\mathbf{2 . 4 9}$ & $\mathbf{0 . 2 1 9}$ & high \\
\hline
\end{tabular}

\section{The table above shows that:}

-The level of difficulties that impede the social worker's exercise of his roles to alleviate the problems caused by bullying among dwarves, as determined by the specialists, averaged with an average weight of (1.71).

- The level of difficulties that impede the social worker's exercise of his roles to alleviate the problems caused by bullying among dwarves, as identified by dwarves, was high with an average weight of (2.49). Which makes us reject the second hypothesis of the study, which is expected to be low in the level of difficulties that hinder the social worker's exercise of his roles to alleviate the problems caused by dwarves' bullying, and this is consistent with what was indicated by (Islam Obaid Ahmed, 2011), where he indicated that the lack of interest The state establishes special institutions to take care of dwarves healthily, socially and psychologically, as one of the disabled groups, which affects the level of service provision for them in light of their suffering from many health, social, psychological, educational and economic problems, in addition to the inferior view of the surrounding community. The study (Walid Salman Abdel Mawjoud, 2011) added that low societal awareness is one of the obstacles that hinder the effective practice of social workers of their professional roles, and the study (Saleh Leary, 2004) added that there are obstacles due to the social institution, and obstacles due to the social worker, and obstacles due to the Community capabilities, and obstacles due to the person receiving the service, in addition to obstacles due to the work team in the institution, all of which prevent the specialist from effectively practicing his work.

The third hypothesis: It is expected that the level of suggestions that help the social worker to exercise his roles to alleviate the problems caused by bullying among dwarves will be high. 
Table (6) shows the level of suggestions that help the social worker to exercise his roles to alleviate the problems caused by bullying among dwarves

\begin{tabular}{|c|l|l|l|l|l|l|l|}
\hline \multirow{2}{*}{$\mathbf{S}$} & The dimension & \multicolumn{2}{c|}{ social workers (N=10) } & \multicolumn{2}{l|}{ dwarves } \\
\cline { 3 - 7 } & & $\begin{array}{c}\text { average } \\
\text { weight }\end{array}$ & $\begin{array}{c}\text { standard } \\
\text { deviation }\end{array}$ & $\begin{array}{c}\text { The } \\
\text { level } \\
\text { order }\end{array}$ & $\begin{array}{c}\text { average } \\
\text { weight }\end{array}$ & $\begin{array}{c}\text { standard } \\
\text { deviation }\end{array}$ & $\begin{array}{c}\text { The } \\
\text { level } \\
\text { order }\end{array}$ \\
\hline $\mathbf{1}$ & $\begin{array}{l}\text { Suggestions that help the social } \\
\text { worker exercise his roles to } \\
\text { alleviate the problems caused } \\
\text { by bullying among dwarves }\end{array}$ & $\mathbf{2 . 7 8}$ & 0.317 & high & 2.51 & 0.150 & high \\
\hline
\end{tabular}

The table above shows that:

- The level of suggestions that help the social worker to exercise his roles to alleviate the problems caused by bullying among dwarves, as determined by the specialists, is high with an average weight of (2.78).

- The level of suggestions that help the social worker to exercise his roles to alleviate the problems caused by bullying among dwarves, as identified by dwarves, is high with an average weight of (2.51). Which makes us accept the third hypothesis of the study, which is that "the level of suggestions that help the social worker to exercise his roles to alleviate the problems caused by bullying among dwarves is expected to be high." Governmental and private institutions by bringing about changes in the status of disabled persons benefiting from services, in addition to giving them the values of self-affirmation and self-esteem and urging them to participate in social activities.

Fourth hypothesis: There are no fundamental differences between the social workers' point of view and the dwarves' point of view about the social worker's exercise of his roles to alleviate the problems caused by bullying among dwarves.

Table (7) shows the differences between the social workers' point of view and the dwarves' point of view about the social worker's exercise of his roles to alleviate the problems caused by bullying among dwarves.

\begin{tabular}{|c|l|l|l|l|l|l|l|l|}
\hline $\mathbf{S}$ & variable & Communty & $\mathbf{N}$ & $\begin{array}{c}\text { average } \\
\text { weight }\end{array}$ & $\begin{array}{l}\text { standard } \\
\text { deviation }\end{array}$ & $\begin{array}{l}\text { degree of } \\
\text { freedom }\end{array}$ & $\begin{array}{c}\text { Values(F) } \\
\text { Values } \\
\text { (T) }\end{array}$ \\
\hline 1 & $\begin{array}{l}\text { The social worker's } \\
\text { exercise of his roles to } \\
\text { alleviate the problems } \\
\text { caused by bullying } \\
\text { among dwarves. }\end{array}$ & $\begin{array}{l}\text { the social } \\
\text { workers }\end{array}$ & 10 & 2.68 & 0.222 & & & \\
\cline { 2 - 9 } & Dwarves & 50 & 2.54 & 0.113 & $* 2.851$ & 14.339 \\
\hline
\end{tabular}

** Significance at $(0.01)$

* Significance at $(0.05)$

\section{The table above shows that:}

-There are significant differences between the point of view of social workers and the point of view of the dwarves about the roles of the social worker to reduce the problems of dwarfs caused by bullying, where the value of the T-test was $\left(2.851^{* *}\right)$, which is significant at $(0.01)$ at the degree of freedom (58), in favor of the point of view of the The view of social workers Which makes us reject the fourth hypothesis of the study, which states that "there are no fundamental differences between the point of view of social workers and the point of view of dwarves about the roles of the social worker to alleviate the problems caused by bullying among dwarves" and this is consistent with the results of Table No. (5), which shows the level of difficulties that hinder The social worker's 
practice of his roles to alleviate the problems caused by bullying among dwarves, and this may be due to the large number and complexity of the problems that the dwarfs suffer from, in addition to the bullying of them by the various media, which led them to withdraw and isolate themselves from participating in community life, as indicated by a study ( Abdul Rahman Syed Suleiman, 2004).

\section{General discussion of the results:-}

- The results of the study proved the validity of the first hypothesis, which states that "the level of social worker practice of his roles to alleviate the dwarfs' problems caused by bullying among dwarves is expected to be high."

-The results of the study proved the incorrectness of the second hypothesis, according to which it is expected that the level of difficulties that impede the practice of the social worker's role to alleviate the problems caused by bullying among dwarves will be low.

- The results of the study proved the validity of the third hypothesis, which states that "the level of suggestions that help the social worker to exercise his roles to alleviate the problems caused by bullying among dwarves is expected to be high."

- The results of the study proved the invalidity of the fourth hypothesis, which states that "there are no fundamental differences between the point of view of social workers and the point of view of dwarves about the roles of the social worker to alleviate the problems caused by bullying among dwarves."

\section{Statistical Analysis Methods:}

The data was processed through the computer using the program (SPSS.V. 24.0) statistical packages for social sciences, and the following statistical methods were applied:

-Frequencies and percentages: to describe the characteristics of the study population.

-Arithmetic mean: to judge the social worker's practice of his roles to alleviate the problems caused by bullying among dwarves, so that the beginning and end of the triple scale categories: OK (three marks), somewhat agree (two marks), disagree (one degree), coded and entered The data was sent to the computer, and to determine the length of the cells of the triangular scale (lower and upper limits), the range $=$ largest value - lowest value $(3-1=2)$ was calculated, divided by the number of scale cells to get the corrected cell length $(2 / 3=0.67)$. ) Then this value was added to the lowest value in the scale or the beginning of the scale, which is the correct one, in order to determine the upper limit of this cell.

- Standard deviation: It is useful in knowing the extent of the dispersion or non-dispersion of the respondents' responses, and it also helps in arranging the phrases with the arithmetic mean, since in the case of the phrases being equal in the arithmetic mean, the phrase whose standard deviation is less takes the highest order.

-Range: It is calculated by the difference between the largest and lowest value.

- T-test for two independent samples. 


\section{The References:-}

1-Abi Al-Fadl Jamal Al-Din: Lisan Al-Arab, (Beirut, Dar Sader Publishing, No. 6, 1997), p. 115.

2-Ahmed Mohamed Sabi: The effectiveness of realistic therapy in serving the individual to alleviate social isolation among dwarves, an unpublished Ph.D. thesis (Helwan University, Faculty of Social Work, 2017).

3- Islam Obaid Ahmed: A study of the biochemical properties and their relationship to the anthropometric measurements of the Al-Jella competition for the dwarves category, an unpublished Master's thesis, Faculty of Physical Education, Helwan University, 2011.

4- Pauline Brugin et al.: "I Have a Place" A Practical Guide for Organizations in the East and the South, (Noor Al-Alam Press, 2012).

5- Tohamy El-Bakry Ahmed: The Actuality of Institutions for the Care of the Physically Disabled in Integrating them into the Community, Master's Thesis, unpublished, Faculty of Social Work, Helwan University, 2010.

6- Arab Republic of Egypt, 2014 Constitution Amendments, Rights and Duties Chapter, Article 81, p. 24. 7-Khaled Al-Najjar: The Concept of Special Categories "People with Special Needs Series" (Al-Mansoura, Dar Al-Ghad Al-Jadeed, 2011).

8- Rania Ben Rizwal, Hadda Youssef: The level of self-assertion among victims of school bullying in the primary stage, a comparative study between victims of bullying and ordinary students, (Algeria, Journal of Psychological and Educational Studies, Vol. 12, No. 2, June, 2019), p. 22: 38.

9- $\quad$ Rahiba Abbas Al-Adly and Ashwaq Jabr Nasser: The relationship between willpower and suicidal thinking among middle school students victims of school bullying (Al-Mustansiriya University, College of Basic Education, 2016, Vol. 22, No. 93), pp. 849-925.

10- Reem Ibrahim Khalaf Abu Zeid: Psychological adjustment and its relationship to social phobia and the self-concept of dwarf students at the university, unpublished master's thesis (Port Said University, College of Education, 2015).

11- Samah Salem Awad Salem and others: Basics of Practice in Community Service, Helwan University, University Book Publishing and Distribution Center, 2020, p. 120.

12-Syed Ahmed Ahmed Mohamed El-Bahas: Psychological security of bullying students and their peers who are victims of school bullying - a psychometric-clinical study, (Benha University, Journal of the College of Education, Vol. 23, No. 9, 2012).

13-Saleh Leary: An exploratory study on the impact of occupational obstacles on the performance of social service for its role in the medical field in the State of Kuwait, Journal of Middle East Research in the Humanities and Literary Sciences, Middle East Research Center at Ain Shams University, 2004. 
14- Tariq Abdel Raouf, Rabie Abdel Raouf Mohamed: People with Special Needs, (Cairo, Thebes for Publishing and Distribution, 2008).

15- Talaat Mustafa Al-Srouji: Social Service, Foundations of Theory and Practice (Cairo, Dar AlHanaa, 2009), p.9.

16- Abdul Rahman Sayed Suleiman: Physical Disability (Concept - Classifications - Treatment Methods), Cairo, Zahraa Al Sharq Library, 2004, 133.

17- Lisan Al Arab Al Muheet, (D.T): Volume Two, Beirut, Dar Al Lisan Al Arab, p. 654.

18- Maher Abu Al-Maati Ali: The General Practice of Social Work in the Medical Field and Care for the Disabled (Cairo, Zahraa Al Sharq, 2004).

19- Maher Abu Al-Maati Ali: The General Practice of Social Work in the Medical Field and Care for the Disabled, (Helwan, University Book Publishing and Distribution Center, 2000), p. 134.

20- Mohamed Sayed Fahmy: The Reality of Caring for the Handicapped in the Arab World, (Alexandria, Modern University Office, 2000).

21- Mohamed Ezzat, Ali Abdullah: A suggested perception from the perspective of general practice in social work to relieve the life pressures of people of short stature, research published in the Journal of Research and Studies in Social Work, No. 55, Faculty of Social Work, Helwan University, 2015.

22- Mohamed Mostafa Zeidan, Mohamed El-Sherbiny: The Psychology of Growth, (Cairo, Egyptian Renaissance Library, 2004).

23- Muhammad Nabil Saad: Social Service and Social Rehabilitation for the Disabled, Damanhar, Princes Press, 2000, p. 87.

24- Medhat Muhammad Abu Al-Nasr: Rehabilitation and Care for the Challenged with Disabilities, Cairo, Etirac for Printing and Publishing, 2004, p. 233.

25- Information and Decision Support Center in the Egyptian Government: Health Profiles of Children in Egypt... Have They Changed, 2012.

26- Maryam Ibrahim Hanna, Social and Psychological Care for Special Groups and the Disabled, Alexandria, Modern University Office, 2010, p. 74.

27- Mustafa Mohamed Qassem, Youssef Mohamed Abdel Hamid: practicing social service in the field of caring for special groups, Fayoum, Nass for Printing, 2006.

28-The comprehensive dictionary of meanings, an Arabic-Arabic lexicon https://www.almaungcom.

29- The Brief Lexicon: The Arabic Language Academy, 1999, p. 501.

30- Al-Wajeez Dictionary, Noor Al-Kutub Library, www.noor.book.com. 
31- Nihal Sami Ahmed Al-Bahouti: Social problems facing dwarves and a suggested perception from the perspective of general practice in social work to deal with them, an unpublished master's thesis ,Helwan University, Faculty of Social Work, 2017.

32- Nihal Suleiman: The Dwarf Society "I was small in body... I weighed the world with my mind, January, 2019.

33- Walid Salman Abdel-Magoud: Obstacles to Community Organization Practice in International Non-Governmental Organizations, Master's Thesis, unpublished, Faculty of Social Work, Helwan University, 2011.

34-American Medical Association : Educational forum on Adolescent Health, Youth Bullying ,United States of America, American Medical Association, 2002.

35-Bonanno, RiaA, Hymel, Shelley: Beyond Hurt feelings: Investigating why some victims of Bulling are at Greater Risk for suicidal Ideation (Merrill- Palmer Quarterly : Journal of Development psychology, 1010, v56, N3 Article 10 p420-440.

36- Cohn, A. and Canter, A. "Bullying facts for Schools Parents (National Association of school psychologists, 4340 East west High way, suite 402, Bethesda , MD, 20814, 2003.

37-Eleni Andreou : Bully/ victim problems and their association with Machiavellianism and self efficacy in Greek primary school children (British Journal of Education psychology, 74(pt2) 297309, July 2004.

38- http://af.com.wikipesia-org-20118.

39- https://www.etwatannews.com/news/details/39.

40-Jessica C. Robert: Mediators of Psychological Ad Just ment In children and Adolescents with short stature, therapeutic out come of Endocrine serono symposia (USA. 2000), pp(119-130).

41-Olweus, Don: Bulling at school, (Unit sites of American, University Oxford, Blach well Publishing, 1993, p.195.

42-Oxford Word Power Second Edition , 2009, p246.

43-Perston, Andrew: Stress and Maladjustment In Adolescents with Short Stature Clinical Pediatrics, vol 44, 2005.

44- Rigby, K and sleep : Suicidal Ideation among Adolescent School Children, Involvement in Bully- victim Problems, and Perceived Social Support (Suicide and life- threatening Behavior, 1999, 29 (2) pp 119-130.

45-Sampson, R: Bullying in School office of Community oriented policing services us. Department of Justice, No (12) 2000

46- Vilhjalmsson, et al "Bodily Deviations and Body Image in Adolescence, article Journal youth and society v44 N3, p366-384, sep 2012. 
47- W.h.O: Deafness and hearing Impairment www.des.info,2000).

48-Tran,Uyen,n,etal: Relationship Between Childhood Short Stature and Academic Achievement in Adolescents and Young Adults- A longitudinal Study, Journal of Pediatrics and Child Health, Vol.46,2010.

49-Abd- Allah, N, Drummond, Short Stature, Increased in Children with Severe Learning Disability, Child Health and Development, Vol.35,2009.

50-Robert, Barker: The Social Work Dictionary, 4 Edition, Woshing Ton, National Assosiation of Social Workers, 1999, p4. 